University of Montana

ScholarWorks at University of Montana

Global Humanities and Religions Faculty

Publications

Global Humanities and Religions

Spring 1994

\title{
"Proper" Men and "Fallen" Women: The Unprotectedness of Wives in Othello
}

Ruth Vanita

University of Montana - Missoula, ruth.vanita@umontana.edu

Follow this and additional works at: https://scholarworks.umt.edu/libstudies_pubs

Part of the Feminist, Gender, and Sexuality Studies Commons

Let us know how access to this document benefits you.

\section{Recommended Citation}

Vanita, Ruth, "'Proper" Men and "Fallen" Women: The Unprotectedness of Wives in Othello" (1994). Global Humanities and Religions Faculty Publications. 3.

https://scholarworks.umt.edu/libstudies_pubs/3

This Article is brought to you for free and open access by the Global Humanities and Religions at ScholarWorks at University of Montana. It has been accepted for inclusion in Global Humanities and Religions Faculty Publications by an authorized administrator of ScholarWorks at University of Montana. For more information, please contact scholarworks@mso.umt.edu. 


\section{Rice University}

"Proper" Men and "Fallen" Women: The Unprotectedness of Wives in Othello Author(s): Ruth Vanita

Source: Studies in English Literature, 1500-1900, Vol. 34, No. 2, Elizabethan and Jacobean

Drama (Spring, 1994), pp. 341-356

Published by: Rice University

Stable URL: http://www.jstor.org/stable/450905

Accessed: 13/01/2014 18:02

Your use of the JSTOR archive indicates your acceptance of the Terms \& Conditions of Use, available at http://www.jstor.org/page/info/about/policies/terms.jsp

JSTOR is a not-for-profit service that helps scholars, researchers, and students discover, use, and build upon a wide range of content in a trusted digital archive. We use information technology and tools to increase productivity and facilitate new forms of scholarship. For more information about JSTOR, please contact support@jstor.org. 


\title{
"Proper" Men and "Fallen" Women: The Unprotectedness of Wives in Othello
}

\author{
RUTH VANITA
}

A surprisingly large number of Elizabethan and Jacobean plays represent or culminate in the murder of a wife, the reason cited almost always being her infidelity. ${ }^{1}$ The plays construct these murders, often led up to by beating and torture of the wife, as tragedy, yet endorse them as a form of justice.

These tragedies have come to be known as "domestic tragedies," suggesting that the events are private, springing from a familial relationship, unlike tragedies which involve political murders and take place in the public sphere. An unresolved contradiction is evident in the titles of these plays which signal the intention to preach a public sermon to women, for example, Women Beware Women, A Woman Killed with Kindness, and A Warning to Fair Women. In Othello, this contradiction is forced to the surface, as the private is insistently made public.

One of the questions that has most vexed critical commentary on Othello is that of the responsibility for Desdemona's death, some critics ascribing it to Othello, others to Iago, others to both, and yet others to Desdemona herself. ${ }^{2}$ Emilia's death has not, until very recently, received comparable attention, and it is agreed that Iago is solely responsible for her death. My argument is that Desdemona and Emilia die similar deaths for similar reasons. In

Ruth Vanita teaches English at Miranda House, Delhi University. Her doctoral work was on Virginia Woolf's critique of love and marriage; she has published essays on Shakespeare, Austen, and Shelley, and this essay is part of her ongoing work on the representation of wife-murder in Renaissance drama. She was coeditor of Manushi: A Journal about Women and Society from 1979 to 1990 . 
each case, the death blow is struck by one particular individual, but it is made possible by the collusion of a number of others who act on the assumption that husband-wife relations are governed by norms different from those that govern other human relations. These men, who spontaneously intervene to save a man from another man's violence, remain ineffectual, albeit deploring, spectators of the escalating violence inflicted by husband on wife. Their failure to intervene and prevent what they deplore is the crucial cause of Desdemona's and Emilia's deaths, insofar as an intervention to save these lives is dramatically presented as viable and possible.

The peculiar painfulness of Othello that many commentators have felt, springs from its dramatization of the ordinary, the normal, and its revelation of that normality as innately brutal and horrifying. Most Indian women students perceive Othello's behavior as "typical," that is, as normal, husbandly, manly behavior. This concurs with Othello's own insight when he describes murderous jealousy as innate in the husband-wife relationship which posits the wife as the exclusive possession of the husband and is thus at odds with the human condition wherein one can never know another person's inmost thoughts and desires: "O curse of marriage! / That we can call these delicate creatures ours / And not their appetites!" (III.iii.265-67). ${ }^{3}$

Several recent critics have sought to explain Othello's behavior as arising from his insecurity as a black in a racist white society. ${ }^{4}$ However, I would contend that the play forcefully combats racism (which posits blacks and whites as essentially different) precisely by its presentation of Othello as not at all different from any white husband. ${ }^{5}$ The development of his jealousy, the language of property ownership he uses, and his misogynist generalizations about women and marriage, are very similar to those of Leontes, Claudio, Posthumus, and even Thomas Heywood's Frankford in $A$ Woman Killed with Kindness or Chapman's Montsurry in Bussy D'Ambois, two plays about jealous husbands and adulterous wives staged within a year or two of Othello (all three ca. 1602-1604).

The difference between Othello and Shakespeare's other jealous husbands-Leontes, Claudio, Posthumus, Master Ford-is the far greater depth and intensity of Othello's love for his wife. What is interesting is that of all Shakespeare's jealous husbands, the one who is black is the one who wins most sympathy and admiration, not only from all those around him, but also from audiences. Othello's blackness does not diminish his power over his wife. Paradoxically, social prejudice against him results in an outcasting 
of Desdemona which isolates her even more than other wives and places her more completely at her husband's mercy. The murder of a wife is different from many other kinds of murder (for example, those represented in Hamlet and Macbeth) insofar as the victim is more definitely placed in the murderer's power. Leontes, in The Winter's Tale, enunciates the difference most clearly when explaining why it is so much easier and safer for him to kill his wife than to kill her supposed paramour:

Fie, fie! no thought of him:

The very thought of my revenges that way

Recoil upon me: in himself too mighty,

And in his parties, his alliance; let him be

Until a time may serve. For present vengeance,

Take it on her...

They should not laugh if I could reach them, nor Shall she, within my power. ${ }^{6}$

A woman's lack of "parties" and "alliance" to come to her aid against a murderous husband renders her an easily available victim. The actual killing is generally the culmination of an escalating continuum of violence, a process represented in both Othello and The Winter's Tale. If Desdemona dies, it is not merely for the formal reason that Othello is a "tragedy" and has to end in death. The tragedy is shown at every point to be avoidable and finally occurs because those who should intervene fail to do so. Society's covert condemnation of Desdemona for choosing to marry a black man reinforces the prejudice that what happens between husband and wife is a private and domestic affair in which no one should interfere. Emilia's death at her husband's hands is again attributable to the onlookers' nonintervention. This is one of the rare cases where wife-murder is represented as occurring because Emilia is "unfaithful" not sexually but mentally. She breaks faith with Iago by choosing to be loyal to Desdemona rather than to him. The dramatic presentation of the two murders as parallels sharply undercuts the dominant ideology that legitimized the murder of an adulterous wife.

Despite S.N. Garner's elucidation of Desdemona's extreme situation, cut off from father and countrymen, a compulsion which renders her powerless, the myth of her passivity dies hard. ${ }^{7}$ David Farley-Hills is the latest in a long line of critics who term her passive and relate this passivity to the stereotype of the patient Griselda. ${ }^{8}$ 
The disinherited Desdemona is a stranger in Cyprus, her only status being that of Othello's wife. He, on the other hand, has lived in Cyprus before and has many friends: "How does my old acquaintance of this isle? / Honey, you shall be well desired in Cyprus: / I have found great love amongst them" (II.i.197-99). When Othello contemplates the possibility of divorcing her, he is aware that she will have nowhere to go: "I'd whistle her off, and let her down the wind / To prey at fortune" (III.iii.260-61). Desdemona uses a more explicitly economic term "beggarly divorcement" in the scene where her desperation is evident in her seeking Iago's intervention:

Good friend, go to him; for, by this light of heaven, I know not how I lost him. Here I kneel:

If e'er my will did trespass 'gainst his love

Or that I do not yet, and ever did,

And ever will-though he do shake me off

To beggarly divorcement-love him dearly, Comfort forswear me! Unkindness may do much,

And his unkindness may defeat my life,

But never taint my love. I cannot say "whore":

It does abhor me now I speak the word;

To do the act that might the addition earn

Not the world's mass of vanity could make me.

(IV.ii.149-63)

The underlying trend of thought here suggests that the alternatives before a divorced woman in her position would be to die in destitution like Barbary, or to become a whore like Bianca. Since the latter is impossible for her, it is the former that she envisages in the unrobing scene. ${ }^{9}$

Given this absence of viable options, patient submission is the best survival strategy. It may win Othello over, as it did many husbands in legend. If it does not, Desdemona has the consolation of having behaved with exemplary virtue. Her apparent fatalism ("It is my wretched fortune" [IV.ii.127]) is the inevitable product of a situation she realistically perceives as offering no escape route.

Desdemona foresees her death but fights for her life with every means available to her. She tries to find allies. The only Venetians who are at hand are Iago, Emilia, and Cassio. Cassio is himself alienated from Othello and in need of a mediator. Therefore, Iago is the only possible ally. She asks him to go to Othello and plead 
her case. In reply, Iago offers all the timeworn excuses offered for violent husbands: "I pray you, be content: 'tis but his humour; / The business of the state does him offence, / And he does chide with you" (IV.ii.164-66). When Emilia's indignation bursts forth, he tells her to "speak within door," that is, as M.R. Ridley aptly glosses: "speak lower; 'you don't want the whole street to hear'; Onions notes that in Warwickshire the phrase 'Speak within the house' was current till recently in the same sense. ${ }^{10}$ And, finally, Iago advises her not to express her grief, but to act normally in the hope that Othello will reform as inexplicably as he has degenerated: "Go in, and weep not; all things shall be well" (IV.ii.171).

Iago's speeches here are not especially "villainous"; they are typical of the advice routinely offered to victimized wives by family, neighbors, and friends. In fact, Iago's villainy is as successful as it is because he speaks to the lowest common denominator, the most widely accepted prejudices. ${ }^{11}$ This is the case not just in his manipulation of Othello, but here, in the mischievous counsel offered to Desdemona. Desdemona faithfully tries to implement his advice by being obedient and meek, a strategy the play reveals as singularly ineffective. Desdemona is not presented as patient Griselda-representations of the latter kind of heroine show patience as a strategy that works; in Othello it does not. ${ }^{12}$

While Iago counsels patience, Emilia's impatience continues to explode, and she makes the most telling comment on Desdemona's predicament: "Hath she forsook .../ Her father, and her country, all her friends, / To be called whore?" (IV.ii.124-26). The scene presents Emilia as Desdemona's only ally, but Emilia is a powerless wife like Desdemona herself.

Before this, however, Desdemona had tentatively sought another ally-Lodovico, whose role I should like to examine in some detail. ${ }^{13}$ Helen Gardner notes that the sensible strategy of leaving Othello and going home with the messengers from Venice never occurs to Desdemona. ${ }^{14}$ While Desdemona does not express any desire to leave Othello, she does express gladness at the news that he has been recalled to Venice, and thus, implicitly, at the idea of going home.

Lodovico arrives in Cyprus when Desdemona is aware of Othello's displeasure with her but not of her own danger. Lodovico is her kinsman, come from her home, her native city. He thus represents, or should represent, some form of support for her. When he appears on stage in IV.i, Desdemona is with him and her form of addressing him (she twice calls him "cousin") shows an 
awareness of kinship. She is also eager for news from home: "And what's the news, good cousin Lodovico?" (IV.i.218). She is happy at the news that Othello is recalled to Venice-"By my troth, I am glad on't" (IV.i.238)-and her innocent expression of happiness is misinterpreted by Othello who strikes her. When Lodovico mildly requests him to "make her amends" Othello responds by heaping further insults on her and then storming out.

In his conversation immediately following with Iago, Lodovico expresses shock, and Iago warns him that the blow was no aberration but the symptom of a rapidly deteriorating situation: "yet would I knew / That stroke would prove the worst!" (IV.i.27576). The implication, that Desdemona is in danger of further maltreatment, is clear. Yet Lodovico makes no attempt to intervene, to speak to Desdemona in private, or to question Othello as to the reasons for his anger. When we next see him, after the dinner hosted by Othello, Lodovico conducts himself with ceremonious formality. He speaks in a way that distances him equally from Othello and Desdemona and the responses he receives are couched in the same kind of formal language:

Lodovico. I do beseech you, sir, trouble yourself no further. Othello. O, pardon me: 'twill do me good to walk.

Lodovico. Madam, good night. I humbly thank your ladyship. Desdemona. Your honour is most welcome.

(IV.iii.1-4)

Thus sent to her deathbed by the irresponsible formality of Lodovico's "good night," Desdemona responds by addressing him as "your honour," not the earlier, intimate "cousin." 15 For Lodovico does not act the part of a cousin. One may contrast with his uncaring behavior here Hero's cousin Beatrice's response to the public dishonoring of her kinswoman, and Laertes' fury at the betrayal of his sister. Lodovico's response suggests that the First Senator's parting injunction "Adieu, brave Moor: use Desdemona well” (I.iii.287) in fact represented her community's acceptance of the idea that, disowned by her father, she henceforth would be wholly at the disposal of Othello.

At an individual level too, Lodovico betrays an unwillingness to take any personal risk in order to help victims of violence when he disregards Cassio's and Roderigo's cries for help, with the canny "Let's think't unsafe / To come in to the cry without more help" (V.i.43-44). Roderigo's response “Nobody come? Then shall I bleed to death" does not move either Lodovico or Gratiano to go to his 
help. When Iago comes in and asks who called out, Lodovico replies "We do not know" (line 47), and when Iago goes to Cassio's aid, he comments admiringly on what he sees as Iago's intrepidity: "a very valiant fellow" (line 52 ).

I suggest that it is this dimension of Lodovico that Desdemona comments on in the unrobing scene. Her comments represent a crux which has never been satisfactorily resolved. Critics have read her comments as straightforward praise of Lodovico, and have interpreted them as either irrelevant women's chatter, or as signs of Desdemona's sensuality and flawed innocence. ${ }^{16}$ However, a reading of the lines as ironical fits in much better with the trend of thought in this scene which focuses on male-female relations as experienced and perceived by women, and ends with Emilia's magnificent dissection and condemnation of the double standard of sexual morality. Desdemona's comment "This Lodovico is a proper man" (IV.iii.34) interjected into her memories of her mother's forsaken maid and her premonitions of her own approaching death, anticipates her cry "O these men, these men!" (line 57). The word "proper" is used with similar irony by Beatrice in Much Ado about Nothing in a very similar situation:

Is a' not approved in the height a villain, that hath slandered, scorned, dishonored my kinswoman? . . . O God that I were a man! I would eat his heart in the market-place. . . Talk with a man out at a window-a proper saying $!^{17}$

Emilia misinterprets Desdemona's subtle irony when she replies "A very handsome man." Desdemona answers "He speaks well," an ironical reference to Lodovico's elaborately polite speeches that mask his fatal failure to act the proper role of a man. Again, a close parallel is available in Beatrice's angry comment on men's fine speaking and lack of chivalry in action when Benedick refuses to kill Claudio who has traduced Hero:

O that I were a man for his sake! or that I had any friend would be a man for my sake! But manhood is melted into curtsies, valor into complement, and men are only turned into tongue, and trim ones too.... I cannot be a man with wishing, therefore I will die a woman with grieving.

The last line sums up Desdemona's life. She began by wishing for a man's adventurous existence ("she wished / That heaven had 
made her such a man" [I.iii.161.62]) and dies, grieving, trapped in the predicament of a woman. Emilia's failure to understand what Desdemona is saying here completes Desdemona's isolation. ${ }^{18} \mathrm{At}$ this point, Desdemona alone grasps the gravity of the situation, Emilia dismissing her anticipation of imminent death: "Come, come, you talk" (IV.iii.24).

Desdemona is killed not only by Othello and Iago but also by all those who see her humiliated and beaten in public, and fail to intervene. The presumption that husband and wife, even when literally in a public space, metaphorically inhabit a private space wherein violence is somehow different from the violence of one man on another fosters the development of a continuum of violence that escalates from abuse to beating to killing. Lodovico's role, as a Venetian and a kinsman, is crucial in the play's exposure of this pattern.

Interestingly, Thomas Rymer, one of Shakespeare's earliest critics, is perhaps the only one to comment on Lodovico's failure to aid Desdemona. In A Short View of Tragedy (1693) he writes:

her Father... sends his Kinsman, Seignior Ludovico, to Cyprus... who, at his arrival, finds the Moor calling the Lady, his Kinswoman, Whore and Strumpet, and kicking her: what says the Magnifico?

Lud. My Lord, this would not be believ'd in Venice, Tho' I should swear I saw't; 'tis very much;

Make her amends: she weeps.

... What Tramontain could fancy the Venetians so low, so despicable, or so patient? ${ }^{19}$

Rymer reads Lodovico's behavior as evidence of Shakespeare's incompetence as a dramatist; it is possible, however, to read it as a representation of the societal "hands-off" approach to marital relations.

A clear contrast is provided by the reaction of all onlookers to the striking of Montano by Cassio. This is treated as a public act, a crime that must, like any act of cognizable violence even today, be pursued and punished by the state. A trial is virtually conducted on the spot, witnesses forced to testify, and Cassio's drunken state not admitted as an excuse. Othello feels compelled by social pressure to punish Cassio harshly even though he would much rather not. Iago's conjecture about Othello's state of mind: "You are but now cast in his mood-a punishment more in policy than 
in malice" (II.iii.265-67) is borne out by Emilia's later report of the private conversation between Othello and Desdemona:

The Moor replies

That he you hurt is of great fame in Cyprus,

And great affinity; and that in wholesome wisdom

He might not but refuse you; but he protests he loves you

And needs no other suitor but his likings

To take the safest occasion by the front

To bring you in again.

That Montano has "great affinity" or "kinsmen of high rank" ${ }^{20}$ is the crucial reason why Othello cannot overlook Cassio's assault on him. Violence on a male produces an immediate counterreaction. Othello is the only one of Shakespeare's major tragedies in which the innocent victim is put to death before our eyes after systematic physical and mental torture in the presence of witnesses, and this is possible because she is a wife.

Societal collusion in husbandly violence is dramatized more starkly in the death of Emilia. Carol Thomas Neely and Eamon Grennan, ${ }^{21}$ among others, have emphasized the importance of Emilia's courageous intervention on Desdemona's behalf, and her deliberate taking of risks to do so when she asserts the power of nonviolent resistance against the power of destructive violence: "Thou hast not half that power to do me harm / As I have to be hurt" (V.ii.161-62). However, the similarity of the two deaths has not been sufficiently commented upon.

Desdemona, dying, gives Emilia the responsibility of clearing her name, much as Hamlet charges Horatio to tell his story to the unsatisfied. "Commend me to my kind lord" (V.ii.126) is an injunction that Emilia literally fulfills. ${ }^{22}$ The way she is killed is a condensed version of the more long-drawn-out process of Desdemona's murder.

Emilia is not killed by Iago alone, as Desdemona was not killed by Othello alone. The other men present, by their inaction, literally create the space, as Lodovico did metaphorically, wherein a wife can be killed by her husband. At line 221 Iago draws his sword and is observed to do so, Gratiano calling attention to the action with "Fie! / Your sword upon a woman!" (V.ii.221-22). Yet, even though it is evident by this time that Emilia is exposing Iago's guilt and is therefore in need of protection (like any state witness), none of the men present makes a move to disarm Iago. What we 
see on stage at this point is a lone unarmed woman surrounded by armed men who deliberately fail to protect her-a visual presentation of the defenselessness of a wife. Iago, with his sword drawn, continues to abuse Emilia in increasingly violent terms but it is only twelve lines later that he stabs her. At the moment he stabs her, Othello simultaneously tries to stab him. Montano immediately disarms Othello with the result that Iago is able to kill Emilia and run away. What we see in this piece of stage business is two people being simultaneously assaulted-one a murderer, the other the woman who has exposed him. He is armed, she unarmed. And, in this moment, the man who intervenes does so to save the murderer, not his victim. ${ }^{23}$

The rationale behind Montano's apparently illogical behavior is provided by Gratiano: "The woman falls: sure, he has killed his wife" (line 234), and, again: "He's gone, but his wife's killed" (line 236). Iago, like Othello, must be preserved for the state to deal with, but Emilia, a woman and a wife, is a different order of being. Even though she has deliberately transgressed the role of wife to denounce her husband, and even as she declares another allegiance: "Ay, ay: $O$, lay me by my mistress' side" (line 235), she continues to be perceived by the men as the wife of her murderer, adjunct rather than agent. While the moral outrage expressed is real, it is limited, and consequently protest is blunted, by the perception of the husband-wife relation as the most significant element in the violent action, precisely as in Lodovico's earlier comment: "What! Strike his wife!" (IV.i.274).

The dramatization of Desdemona's and Emilia's murders challenges some of the most fundamental assumptions of Elizabethan society and of our own-that outsiders should not interfere between husband and wife, and that an adulterous woman deserves death. The latter idea pervades Elizabethan and Jacobean drama but was by no means restricted to the sixteenth and seventeenth centuries. It surfaces repeatedly in later literary textsto take a famous example, in Goldsmith's lyric "When lovely woman stoops to folly." That the idea is alive and well today is clear from the fact that a number of twentieth-century commentators on Othello and The Winter's Tale have seen Desdemona's and Hermione's behavior as "provocative," thus implicitly arguing that a wife should not only be chaste but should give her husband no grounds to doubt her. ${ }^{24}$

Othello is the only play of its time which carries the chastity test to its logical conclusion by ending with the death of the innocent heroine. Desdemona's chastity fails to save her life. Her death demonstrates that innocent wives subjected to tests and ordeals 
are more likely to end up dead than triumphant. The presentation of her murder on stage is a departure from Shakespeare's normal practice. Michael Neill has documented critics' and producers' disturbed responses to this scene (from Dr. Johnson onward), and nineteenth-century productions' tendency to distance and veil the bed, and James R. Siemon has noted the tendency to tone down the violence of Desdemona's physical struggle with Othello. ${ }^{25}$ Neill suggests that audiences' sense of unease springs from their covert sharing of Iago's and society's horror at the interracial sexual encounter viewed as innately "adulterated" and "adulterous." But the last scene focuses on murder rather than eroticism, on the irrevocability of the act of murder. Questions of chastity and guilt or innocence are submerged in the overpowering focus on life itself. In her last moments, Desdemona realizes that "beggarly divorcement" would be preferable to death: "O banish me, my lord, but kill me not" (V.ii.79). She fights for survival, pleading for one night more, one half hour more, as such heroines as Lucrece pleaded with their ravishers to spare their virtue.

If the audience feels guiltily engaged and hence doubly revulsed, this is not because it is complicit in the perspective of Iago, who is not only physically absent but also forgotten, swept away in the flow of Othello's magnificent rhetoric. The audience, as silent witness, is placed in the position of those men of Cyprus and Venice who silently witnessed the abuse of Desdemona and failed to intervene. The audience is guilty of failing to intervene in the daily drama of domestic violence that lies hidden behind countless bedroom doors in every society where Othello is staged. As Desdemona's bedroom door opens with terrifying finality to let in her licensed "lord" and murderer, the dramatist raises the curtain on the most invisible, least glorifiable, and yet most condoned of all forms of violence-the violence of armed men on the unarmed women within their power. Hermione's trial is far less painful because those who witness it are not silent; they are articulately and actively on her side. Their presence is an indication of hope, of a society whose conscience is alive. Desdemona's aloneness in her bedroom is a more true-to-life representation of the powerless position of wives ${ }^{26}$ Modern productions generally reduce the full force of the scene by darkening the stage. On the Jacobean daylit stage, the candles were mere symbolic props. The audience could not evade or sentimentalize the stark horror of this murder.

Most domestic tragedies' presentations of the torture, selfabasement, and death of the guilty wife were intended as a warning to women, and often display a near-sadistic delight in the woman's sufferings. ${ }^{27}$ We are invited and guided to pass judgment. Othello, 
because of its dual focus-unconditional sympathy for Desdemona, and sympathy for Othello qualified by the uncomfortable awareness of our own culpability in feeling any sympathy with the assumptions upon which he and Iago act-does not allow us to pass judgment without simultaneously judging ourselves. Iago's entire argument is based on the misogynist assumptions that underlay rising Puritan morality; hence the audience could not indict him without some measure of self-questioning.

The effect of the last scene, unique in Shakespeare for the killings of two unarmed women by two armed men, one cast as hero, the other as villain, is surely, in one sense, to render unimportant the question of chastity. Who, watching this play, ever worries about the technicality of Emilia's chastity while she is waging her heroic battle for justice? Michael Neill suggests that the spectacle of the three bodies (Othello, Emilia, Desdemona) on one bed at the end of the play has "a covert suggestion of something adulterous. ${ }^{28} \mathrm{He}$ is here combatting G.M. Matthew's view of the two bodies, one black, one white (Othello, Desdemona) embracing in death as an emblem of the indivisibility of human dignity. ${ }^{29}$

But there is a fairly longish interval before the third body, Othello's, is added to the bed. In that interval, the spectacle of Desdemona and Emilia lying dead together is much more strongly suggestive of how great lady and ordinary gentlewoman are equally defenseless as wives, yet retain their dignity in death. It focuses visual attention on the similarity of their deaths, as their last words focus aural attention: "A guiltless death I die" (V.ii.123) and "So speaking as I think, I die, I die" (line 249).

One of the ironical echoes in Gratiano's statement "The woman falls" may derive from Emilia's earlier denunciation of the double standard: "But I do think it is their husbands' faults / If wives do fall" (IV.iii.86-87). These words occur again in Lodovico's "O thou Othello, that wert once so good / Fall'n in the practice of a damned slave" (V.ii.292-93), and "you shall close prisoner rest / Till that the nature of your fault be known / To the Venetian state" (lines 336-38). The ultimate irony in the play's representation of male-female relations is the fact that two women accused by their husbands of "falling" morally, actually fall not morally but physically, before our eyes, felled by those morally "fallen" husbands' hands and, symbolically, by the male-dominated society which endorses the murder of supposedly fallen women.

Shakespeare's highlighting of the importance of human intervention to save a woman from a murderous husband was not unique in its time. A sixteenth-century Northern English ballad on 
the theme specifically makes the point that onlookers have a duty to stop an enraged man from killing his wife. In this ballad, "Little Musgrave and Lady Barnard," the lady's husband, informed by a pageboy of her love affair, discovers her in bed with her lover. He tells the paramour to arm himself and fight, and kills him in the ensuing encounter. The wife defies her husband, declaring her love for her paramour. He then cuts off her breasts and kills her. The ballad is singularly free from any moralizing comment on the narrative, unlike plays on the theme. Instead, the lady's death is followed by a comment on the pity of the way the lady was killed, and then by the husband's addressing his followers:

He cut her paps from off her brest;

Great pitty it was to see

That some drops of this ladie's heart's blood

Ran trickling downe her knee.

Woe worth you, woe worth, my mery men all,

You were nere borne for my good;

Why did you not offer to stay my hand,

When you see me wax so wood?

For I have slaine the bravest sir knight

That ever rode on steed;

So have I done the fairest lady

That ever did woman's deed. ${ }^{30}$

The idea expressed here, that a husband may go temporarily mad with jealousy ("wax so wood") and that uninvolved onlookers have therefore a greater responsibility to restrain him, a restraint that would be for his good, is an insight particularly appropriate to Othello.

\section{NOTES}

${ }^{1}$ Although such murder was not, strictly speaking, legal in England (as it was in contemporary Venice), a betrayed husband was widely perceived as having the right, almost the duty, to kill his unfaithful wife and her paramour. See Norman Council, When Honour's at the Stake: Ideas of Honour in Shakespeare's Plays (London: George Allen and Unwin, 1973). Council argues that $O$ thello questions this dominant notion, departing from the source story by Giraldi Cinthio in this respect. For the Venetian law, see Rodney Poisson, "Death for Adultery: A Note on Othello," SQ 28, 1 (Winter 1977): 89-92, 90. 
${ }^{2}$ Carol Thomas Neely, Broken Nuptials in Shakespeare's Plays (New Haven: Yale Univ. Press, 1985), pp. 105-108, sums up the controversy and goes on to turn the spotlight on Emilia and her relationship with Desdemona.

${ }^{3}$ Othello, New Penguin Shakespeare, ed. Kenneth Muir (Harmondsworth: Penguin Books, 1968). All references are to this edition, and will appear in the text.

"Martin Orkin, in "Othello and the 'plain face of Racism," $S Q, 38,2$ (Summer 1987): 166-68, demonstrates effectively how the play combats dominant racist assumptions and beliefs. However, he collates men's and women's situations and responses to read the play as a comment on "the inevitable limitations of human judgment" (p. 180). See also G.K. Hunter, "Othello and Colour Prejudice," in Interpretations of Shakespeare: British Academy Shakespeare Lectures, selected by Kenneth Muir (Oxford: Clarendon Press, 1985), pp. 180-207; and Ruth Cowhig, "The Importance of Othello's Race," Journal of Commonwealth Literature 9, 2 (December 1977): 153-61. Ania Loomba in Gender, Race, Renaissance Drama (Manchester: Manchester Univ. Press, 1989) goes further in stressing Othello's vulnerability, and totally ignores Emilia's role in the play. She treats the play in isolation from Shakespeare's other three plays on this theme.

${ }^{5}$ Sarup Singh, The Double Standard in Shakespeare and Related Essays (Delhi: Konark Publishers, 1988): "It is notable that given the same situation, Shakespeare's men, whether black or white, respond in the same way" (p. 29).

${ }^{6}$ The Winter's Tale, The Arden Shakespeare, ed. J.H. Pafford (Methuen: London, 1963), II.ii.181-26.

${ }^{7}$ S.N. Garner, "Shakespeare's Desdemona," ShSt 9 (1976): 233-52, sums up earlier responses to Desdemona and emphasizes her isolation.

${ }^{8}$ David Farley-Hills, Shakespeare and the Rival Playwrights, $1600-06$ (London: Routledge and Kegan Paul, 1990). Farley-Hills's predilections are evident in his comment on the unrobing scene as presenting a "contrast between the sensitive Desdemona ... and the coarser-grained but well-meaning Emilia, chattering about women's rights" (p. 108).

${ }^{9}$ The irony is exacerbated by Bianca's fate. Both Desdemona and Emilia, perceived by their husbands as unfaithful, are termed prostitutes. Iago calls Emilia "Villainous whore" (V.ii.227) just before he kills her, as Othello, strangling the struggling Desdemona, berates her: "Down, strumpet" (line 80 ). Bianca, called a prostitute by Cassio, shows her faithful love for him by rushing to his side when he is wounded, oblivious of the risk to herself. Iago arrests her on no evidence other than her reputation as a "strumpet" (V.i.78), a reputation she disputes. On this occasion too, none of the men present intervenes to save her, even Emilia self-righteously joining in her condemnation. This scene, immediately preceding the murder scene as it does, underlines the equal vulnerability of women, married or unmarried, to the violence of men.

${ }^{10}$ M.R. Ridley, in Othello, ed. Ridley, Arden Shakespeare (London: Methuen, 1955), gloss, p. 158.

${ }^{11}$ As Peter Stallybrass puts it, Iago's "is the voice of 'common sense,' the ceaseless repetition of the always-already 'known,' the culturally 'given," "Patriarchal Territories: The Body Enclosed" in Margaret W. Ferguson, Maureen Quilligan, and Nancy J. Vickers, eds., Rewriting the Renaissance (Chicago: Univ. of Chicago Press, 1986), p. 139.

${ }^{12}$ Puritan tracts and homilies of the time routinely handed out the Iago kind of advice to women, telling them to be silent and submissive, and endure 
even maltreatment by the husband. See Sarup Singh, and Lisa Jardine, Still Harping on Daughters (Sussex: Harvester-Wheatsheaf, 1983), esp. chap. 6, where she reads Desdemona as cast in the patient Griselda mold.

${ }^{13}$ Lodovico's role has never, to my knowledge, been adequately dwelt upon, although Desdemona's comments on him in the unrobing scene have led to endless speculation about her.

${ }^{14}$ Helen Gardner, "The Noble Moor" in Interpretations of Shakespeare, pp. 161-79; 175.

${ }^{15}$ That Desdemona is "publicly struck" in the presence of "men," and can subsequently "acquit herself with ... decorum" at a formal banquet is seen by Ridley as a sign of her "quality" (Ridley, Introduction, p. lxv). Another kind of reading is more concerned with Othello's than Desdemona's pain: "His striking her in public . . . is a symbolic act, a calling the world's attention to the intolerableness of what he suffers by the intolerableness of what he does" (Winifred Nowottny, "Justice and Love in Othello," University of Toronto Quarterly 21 [1952], 339). No critic appears to notice the role of the onlookers here, especially of Lodovico.

${ }^{16}$ S.N. Garner sums up the critical debate between those who see Desdemona as saint and those who see her as slut, the former ignoring, explaining away, or, like M.R. Ridley, wishing to transfer the lines to Emilia, the latter, like W.H. Auden, reading them as evidence of Desdemona's sensual interest in men. The lines are central to Garner's argument that Desdemona is represented in the play as fully human. According to him, "Since the man Desdemona has married, and risked her social position for has turned into a barbarian, she unconsciously longs for a man like Lodovico. . . . In her heart she must feel she has made a mistake" (p. 249). This speculation about what Desdemona "must feel" springs from what Garner himself feels-that the marriage is a doomed misalliance which "must fail" (p. 250), an assumption colored with racist feeling; see note 25 below. The lines are also central to Lisa Jardine's argument that Shakespeare represents Desdemona as culpable, based on the "patriarchal assumption" that she is driven by sensuality in marrying a black man. Jardine reads Iago's view as "a relevant view of Desdemona throughout the play" (p. 75).

${ }^{17}$ Much Ado About Nothing, New Shakespeare, ed. Sir Arthur Quiller-Couch and John Dover Wilson (Cambridge: Cambridge Univ. Press, 1971), IV.i.300309 . All references are to this edition and subsequently will appear in the text.

${ }^{18}$ Such miscommunication between two people holding a conversation is characteristic of Othello. People frequently misread speech, deriving a meaning opposite to that intended by the speaker. This is an important dimension of the representation of a society that fails to check injustice and violence, allowing them to build towards tragedy.

${ }^{19}$ Thomas Rymer, A Short View of Tragedy (1693) extracted from Othello: A Casebook, ed. John Wain (London: Macmillan, 1971), pp. 37-48, 40.

${ }^{20}$ Ridley, gloss, p. 92.

${ }^{21}$ Neely, and Eamon Grennan's sensitive exegesis in "The Women's Voices in Othello: Speech, Song, Silence," SQ, 38, 3 (Autumn 1987): 275-92.

${ }^{22}$ Desdemona's dying "lie," "Nobody. I myself," bears an uncanny resemblance to the dying statements given by hundreds of Indian women over the last two decades to police and doctors, declaring their deaths suicides, thus exonerating the husbands and in-laws who murder them. See, for instance, "Letters Written at Death's Door," Manushi 1 (January 1979): 1314. In the context of the masculine obsession with revenge displayed in the 
drama of the period, Desdemona's nonpunitive attitude would seem to signify women's insight that to follow the logic of an eye for an eye would be to make the whole world blind.

${ }^{23}$ The Quarto stage direction "He runs at Iago. Iago stabs Emilia" only confirms the indications built into both the Folio and the Quarto text that Montano intervenes to disarm Othello.

${ }^{24}$ On The Winter's Tale, see, for example, Nevill Coghill, "Six Points of Stage-craft in The Winter's Tale," ShS 11 (1969): 31-41, and the much more sophisticated argument of Howard Felperin, "Tongue-tied our queen?-The Deconstruction of Presence in The Winter's Tale," in Shakespeare and the Question of Theory, ed. Patricia Parker and Geoffrey Hartman (New York: Methuen, 1985), pp. 3-18.

${ }^{25}$ Michael Neill, "Unproper Beds: Race, Adultery and the Hideous in Othello," SQ 40, 4 (Winter 1989): 383-412; and James R. Siemon, "Nay, that's not next': Othello V.ii. in Performance, 1760-1900," SQ 37, 1 (Spring 1986): 38-51. Siemon too sees the "mixture of violence and eroticism" in the last scene as giving rise to the discomfort of critics and directors which led to its toning down in production so that the murder appeared a sacrifice (p. 39).

${ }^{26}$ With a characteristic flash of insight, A.C. Bradley noted in Othello "the darkness not of night, but of a close-shut murderous room" (Shakespearean Tragedy [London: 1904; rprt. Macmillan, 1969], p. 177). S.N. Garner makes a surprisingly racist comment when contrasting Desdemona with Hermione: "She acts differently from the heroine of The Winter's Tale not only because she is more fragile and less wise but also because her accuser is not a white man following at least the forms of justice in a court. Othello is a black man with rolling eyes coming to do 'justice' in her bedroom at night" (p. 249). He forgets that many other white men on the Elizabethan stage executed precisely such justice as did Othello, and that in Cymbeline, a white man, Posthumus, tries to do "justice" by proxy, instructing his servant to lure Imogen into a forest and murder her there.

${ }^{27} \mathrm{~A}$ Woman Killed with Kindness is a good example of such plays that wallow in self-righteous sadism masquerading as Christian charity. See my essay "Men Beware Men: Shakespeare's Warnings for Unfair Husabands," forthcoming in Comparative Drama (Summer 1994), for a detailed consideration of Othello as a response to Heywood's play.

${ }^{28}$ Michael Neill, p. 407.

${ }^{29}$ G.M. Matthews, "Othello and the Dignity of Man," in Arnold Kettle, ed., Shakespeare in a Changing World (London: Lawrence and Wishart, 1964), pp. 123-45.

${ }^{30}$ The Faber Book of Ballads, ed. Matthew Hodgart (London: Faber and Faber, 1965; rprt. 1971), pp. 60-64, 64. 